\title{
The Role Of Transformational Leadership In Improving Job Satisfaction
}

\author{
Ida Rianty $^{*}$ ) \\ ${ }^{*}$ Universitas Islam Negeri, Jambi, Indonesia \\ Corresponding Author: idarianty68@yahoo.co.id
}

\begin{abstract}
The purpose of this study to determine the role of Transformational Leadership in increasing Job Satisfaction. The samples have been taken by random sampling technique selecting amounted to 249 samples from permanent lecturers of private Islamic High School in Jambi Province. This research uses a Sequential Explanatory Design Mixed Method that is first research using a quantitative method then deepen it with a qualitative method. This is intended to result in more in-depth and comprehensive research.

The result shows that there is a positive correlation between transformational leadership which has a high effect on job satisfaction of the lecturers. The coefficient correlation is ry $=0,483$ and coefficient determination ry $=0,233$. It means that $65.90 \%$ of job satisfaction is influenced by transformational leadership, and the rest of it influenced by other factors.
\end{abstract}

Keywords: transformational leadership, job satisfaction, and permanent lecturers.

\section{INTRODUCTION}

As an educator, the lecturer has a very decisive role in carrying out the Tri Darma of the Higher Education. On the other hand, the lecturer also acts as a curriculum coach, controller of academic regulations, the creator of the student learning climate, a figure who influences the intellectual and social environment of life on campus, and lecturers are the people who know the real process of implementing education on campus. The role of lecturers as professionals has four responsibilities. First, related to morality, lecturers are required to live, practice, and pass on Pancasila to students and the younger generation. Second, related to education, lecturers can manage the education process for students in the form of teaching, guidance and so on. Third, related to society, lecturers are required to improve the quality of life of the community, foster unity and unity, and participate in the national, regional and surrounding community development processes. Fourth, related to science, lecturers are required to advance science and technology, especially in the field of expertise.

Job satisfaction is closely related to the attitude of lecturers towards various factors in work, including work situations, social influences on work, rewards and leadership and other factors. However, in practice sometimes the factor of job satisfaction is less attention from the organization and leadership, this can be an obstacle for the organization. If job satisfaction can already be felt by members, then naturally the motivation and motivation will increase, thus automatically increasing its performance towards the organization.

Based on the results of a preliminary research survey conducted by researchers through the dissemination of instruments to 20 permanent lecturers of Region XIII Kopertais in Jambi Province, 4 Colleges in Jambi Province are: (STAI Ma'arif Jambi City, STIT Al-Azhar Diniyah Jambi City, STAI Al-Anwar Kuala Tungkal and STAI Ahsanta City of Jambi) related to job satisfaction conducted shows that many lecturers still have problems.

Basically job satisfaction is something that is individual, each individual will have a different level of satisfaction in accordance with the system of values that exist in him. This is due to differences in each individual, the more aspects of work that are in accordance with the wishes of the individual, the higher the level of satisfaction is felt, and vice versa. Many aspects affect job satisfaction, including aspects of work-related feelings such as the amount of salary received, career development opportunities, relationships with other employees, organizational culture, transformational leadership, work placement, type of work, work motivation, and corporate organizational structure. In addition, job satisfaction relates to five core dimensions of job characteristics, namely diversity of skills, task identity, meaning of tasks, autonomy and feedback.

Colquitt, LePine, and Wesson (2009) define work satisfaction as a pleasant emotional state, resulting from an assessment of work or work experience. In other words, job satisfaction shows 
someone's feelings about their work and what they think about the job. Employees with high job satisfaction will have experience of positive feelings when they think about their duties or take part in their work and employees with low job satisfaction will have experience of negative feelings when thinking about their assignments or taking part in their work. Wexley and Yuki define, "job satisfaction is the way workers feel about their work. Job satisfaction is influenced by several aspects of work, including: (a). Salaries / wages (b). Working conditions, (c). Supervision (d). Working friends, ((e.) Job material, (f). Job guarantee, (g). Opportunities to advance. "

According to J.L. Gibson, J.M. Ivancevich, J.H. Donnelly, Jr., and R. Konopaske (2006), Job Satisfaction is an individual's attitude towards his work, which originates from his perception of his work, with indicators: (a). Pay is salary / wages, (b). Job is the conditions of work: means, challenges, terms of office, (c). Promotion Opportunities are promotion opportunities, career development, status improvement, (d). Supervisors are supervisor supervision, supervisorsubordinate relationship, (e). Co-Workers are coworkers. Rue and Byars (2007) define: "Job satisfaction refers to the general attitude of an employee towards his work. This can be influenced by factors such as employment conditions, salaries and benefits, employee attitudes toward the organization, supervision of their work, age and health of employees. Laurie J. Mullins (2005) explains that job satisfaction is a pleasant feeling that results from the perception that someone's work fulfills or allows for the fulfillment of the important values of one's work. T.Hani Handoko (2008) defines job satisfaction as a pleasant or unpleasant emotional state by which employees view their work. Job satisfaction reflects a person's feelings about his work. There are several reasons that cause employees to be satisfied with their work, including: (a) Work experience, (b) age of employees, (c) adjustments in work, (d) level of employment, (e) compensation, (f) conditions of work, (g) and appreciation for the competencies of employees.

Colleges in achieving their organizational goals must be supported by human resources as well as the existence of a reformist leader who cares about change and can provide an important role in the running of the organization. In accordance with its role, leaders as directors and goals in the future (direct setter), change agents (agent of change), negotiators (spokespersons), and as coach (coach) in moving all components or organizational resources to achieve goals. Therefore, a leader must be able to direct motivation by creating organizational conditions (climate) through the formation of an organizational culture so that members feel encouraged to work harder so that the performance achieved is also high. A very strategic and important leadership role in achieving the mission, vision and goals of the organization is one of the motives that encourage people to investigate deeply related to leadership. Apart from that the leader is also very instrumental in the growth and development of organizational culture in his organization.

Bernard M. Bass \& Ronald E. Riggio (2006) defines transformational leadership as a behavior that stimulates and inspires followers to achieve results and in the process of developing their leadership abilities, vision and goals given by their organizations, challenges themselves to innovate, solve problems and develop abilities leadership of his subordinates through direction, mentoring, and giving challenges and support. Gary Yuki (2006) stated that transformational leadership is the behavior of a leader who is able to call moral values on his followers in their efforts to increase their awareness of ethical issues and mobilize their energy and resources to reform institutions.

Jason A. Colquitt, Jefrey A. Lefine and Michel J. Wessor (2009) emphasize the definition of transformational leadership with the statement that transformational leadership occurs when a leader can inspire his subordinates to commit to the vision by giving meaning to work and he acts as a model for his subordinates in developing their potential and problems from a new perspective. Stephen L. MacShane \& Mary Ann von Glinow (2010) stated that transformational leadership is: a leader who changes his team or organization by creating, communicating, and becoming a model for his organizational vision and encouraging his subordinates to fight for the vision of his organization. Related factors are: (a). Creating a strategic vision, (b). Communicating the vision, (c). Become a vision model, (d). Building commitment to this vision. Paul E. Spector (2006) describes transformational leadership as a leader who can inspire others to accept their organization's noble goals and strive to achieve them. The leader is able to express his vision and encourage him to achieve it. Kreitner Kinicki (2005) emphasized that transformational leadership changes its subordinates by creating changes in their goals, values, beliefs and aspirations.

According to Bahar Agus Setiawan and Abd. Muhith (2007), transformational leadership is a process whereby leaders and followers raise themselves to a higher level of morality and motivation as a spirit in the organization, with indicators: (a). Idealized and Influence, (b). Inspirational Motivation, (c). Intellectual Stimulation, (d). Individual Consideration. Based on the above theories, it can be synthesized that transformational leadership is the behavior of a leader who directs his subordinates to use the values that exist today towards the vision and mission that has been set. The dimensions and indicators are as follows: (a). Ideal influence (behavior, showing confidence, generating respect, pride and trust, fostering commitment and performance beyond expectations, and upholding ethical moral behavior). (b) motivational inspiration 
(an attitude that always fosters challenges, is able to achieve high expectations, is able to arouse enthusiasm and motivation of others, and encourage intuition and kindness in others), (c). Intellectual stimulation (the process of increasing understanding and stimulating new perspectives in seeing problems, thinking, and imagining, as well as in establishing trust values), (d). Individual/individual attention (giving special attention, support, enthusiasm and effort on the needs of achievement and growth of its members).

\section{RESEARCH METHODS}

The research method used is a survey method with a correlational approach. The research variable consists of independent variables, namely transformational leadership (X) and the dependent variable is the job satisfaction of the lecturer (Y). The population used in this study were all permanent lecturers of the Regional XIII Kopertais Private Islamic High School in Jambi Province with a total of 16 private Islamic High Schools, as many as 660 permanent lecturers, and spread over 9 regencies 2 cities. By using a random sampling technique there were obtained 249 respondents.

\section{The Quantitative Phase}

To test the research hypothesis and to find out the strength of the relationship between transformational leadership and job satisfaction, the dossier is done with the following analytical techniques:

a) Analysis Requirements Test (Classic Assumption Test). The classic assumption test is testing statistical assumptions that must be met in multiple linear regression analysis based on ordinary least square (OLS).

(1) Normality of Data Distribution Test with Raw Estimated Error

(2) Uji Homogenitas Varians Data

b). Hypothesis testing

(1) Linearity Test and Significance of Linear Regression Equations

(2) Correlation Test : 1) Using simple correlations to see the strength of the relationship of variables $\mathrm{X}$ with $\mathrm{Y}, 2$ ) Using multiple correlation to see the strength of the variable relationship $\mathrm{X}$ with variable $\mathrm{Y}$.

c) Statistical Hypothesis

H0: $1 y 1 \leq 0$ There is no positive relationship between transformational leadership variables (X) with Lecturer Job Satisfaction (Y).

$\mathrm{H} 1: 1 \mathrm{y} 1>0$ There is a positive relationship between transformational leadership variables $(\mathrm{X})$ with Lecturer Job Satisfaction (Y).

\section{The Qualitative Research Phase.}

The main purpose of the qualitative research stage is to verify the results of quantitative research. By departing from the results of quantitative research data, the target of qualitative research is to prove, strengthen, deepen, expand, weaken and even abort quantitative data that has been obtained.

Research focus specifically, this research phase is as follows: Does the results of quantitative job satisfaction research have the same tendency as qualitative transformational leadership. What kind of job satisfaction is there in the population of private Islamic High School lecturers in Jambi Province?

The target of this research was taken by Kopertais Permanent Lecturers in Jambi Province, consisting of 16 Private Islamic Religion Schools.

\section{RESULTS AND DISCUSSION}

Primary data obtained in the field about job satisfaction (Y) through the distribution of 35 questionnaires with a rating scale of 1 s.d. 5 contains answer choices SS (Strongly Agree), S (Agree), R (Hesitate), TS (Disagree) and STS (Strongly Disagree), showing the answers of the respondents described in the table below. In the frequency distribution table above, it can be described that the highest frequency value in the 5 th class is $25.30 \%$ ( 63 out of 249 people) lecturers in the score range 136-141 included in the category of having moderate job satisfaction, $20.48 \%$ (51 of 249 people) lecturers fall into the category of having high job satisfaction and lecturers who have low job satisfaction as much as $19.68 \%$ (49 of 249 people). The thing that needs to be observed from the frequency distribution of job satisfaction variables $(\mathrm{Y})$ is the percentage of lecturers who have low job satisfaction up to the number of lecturers who have job satisfaction is showing a high position, which is equal to $79.52 \%$. The number of lecturers with high job satisfaction reached $20.48 \%$.

The results of the data obtained from the quantitative research above are strengthened by the results of data from qualitative research conducted through interviews, Focus Group Discussions (FGD), observation and documentation studies. The results of the acquisition of qualitative data are thought to be able to answer the focus of the first qualitative research, namely: Does the Job Satisfaction (Y) variable data obtained through quantitative research have the same tendency as the data obtained through qualitative research and what is the Job Satisfaction data (Y) of lecturers in the order of Private Islamic Universities in Jambi Province?

Based on the results of the qualitative research above, it can be concluded that job satisfaction in STAI Ma'arif Jambi City, STIT Darul 'Ulum Sarolangun, STIT Al-Azhar Diniyah has a fairly high category of salary amounts, evaluation of the implementation of lecturer duties by the Program Chair Study, campus facilities and infrastructure, reward system, attention of lecturers 'needs in lectures, opportunities to develop potential, freedom to lecturers to develop lecture systems, and appreciation of lecturers' work. 
Primary data obtained in the field about transformational leadership (X) through the distribution of 35 questionnaires with a rating scale of 1 s.d. 5 contains answer choices Sl (Always), Sr (Frequent), Kk (Sometimes), P (Ever) and TP (Never). In the frequency distribution table above it can be illustrated that the highest frequency value in the 4th class is $24.50 \%$ (61 of 249 people) lecturers have transformational leadership in the score range 129-135 in the category of having moderate transformational leadership, then as many as $6,43 \%$ (16 of 249 people) fall into the category of having high transformational leadership. While those with low transformational leadership were $31.72 \%$ (79 out of 249 peop Transformational leadership instruments consist of 35 valid statement items. The lowest theoretical score is 35 and the highest is 175 , with a theoretical median of $105[(35+175) / 2=105]$. The lowest empirical score is 108 and the highest is 164 , with an empirical average score of 133.26 and median 136 [(108+164) / $2=136]$ means that the distribution of empirical distribution is in the high score area.

This qualitative data was taken from 5 (five) Private Islamic Colleges in Jambi Province which represented the upper group namely STAI Ahsanta Jambi City, representing the middle group namely STAI Ma'arif Jambi City, STIT Darul 'Ulum STIT AlAzhar Diniyyah Jambi City, representing the group lower, namely STIT, Tebo Regency. The data obtained from the quantitative research above is strengthened by the presence of data from qualitative research through interviews, focus group discussions, observation and documentation. The results of the acquisition of qualitative data answer the second qualitative research focus, namely: Does the Transformational Leadership variable (X2) data obtained through quantitative research have the same tendency as the data obtained through qualitative research and what is the Transformational Leadership (X2) data available to lecturers at Private Islamic Colleges in Jambi Province?

The homogeneity of the variance in the data of job satisfaction on transformational leadership was tested using the Bartlett test. Based on the calculation results obtained the value of itungcount $2=120,561$ while abeltable $2=242,647$. Data requirements are called homogeneous if fcount $2<\chi$ table 2 , then the group data on job satisfaction for transformational leadership comes from a homogeneous population. The functional relationship between $\mathrm{X}$ and $\mathrm{Y}$ can be presented in the form of the regression equation as follows: $\hat{Y}=76,287+0,467 X$. To test the hypothesis that there is a positive relationship between transformational leadership (X) and job satisfaction (Y), a significance test and linearity test on the regression equation are needed using the $\mathrm{F}$ test.

Linearity test results obtained $\mathrm{F}$ count $<\mathrm{F}$ table $(0.999<1.413$ at $\alpha=0.05$ and $0.999<1.626$ at $\alpha=$
0.01), which means there is a linear relationship between transformational leadership and job satisfaction. To test the significance of the relationship between transformational leadership and job satisfaction in the regression equation $\hat{\mathrm{Y}}=76,287+$ $0,467 \mathrm{X}, \mathrm{F}$ count $>\mathrm{F}$ table $(40,273>3,879$ at $\alpha=0,05$ and $40,273>6,739$ at $\alpha=0,01)$, this means there a very significant positive relationship between transformational leadership and job satisfaction. The strength of the relationship between transformational leadership variables and job satisfaction is shown by the correlation coefficient ry $2=0.483$. To test the strength of the relationship on a positive relationship between variables $\mathrm{X}$ with variable $\mathrm{Y}$, it is necessary to test the significance of the correlation coefficient, namely by $t$ test. The criteria for testing the significance of the correlation coefficient are if $t$ count> $t$ table. Based on the calculation results obtained $\mathrm{t}$ count $=8.667$ while $\mathrm{t}$ table $=1.970$. This means that the correlation coefficient between transformational leadership and job satisfaction is significant. The coefficient of determination between transformational leadership and job satisfaction is (ry) ${ }^{2}$ $=0.233$. This means $23.30 \%$ variation in job satisfaction can be explained by transformational leadership The hypothesis that there is a positive relationship between transformational leadership and job satisfaction can be accepted, meaning that the higher the transformational leadership, the higher the level of job satisfaction.

Table 1: Calculation Results of the Significance of Transformational Leadership Correlation Test (X2) with Y

\begin{tabular}{|c|c|c|c|c|c|}
\hline \multirow{2}{*}{$\begin{array}{l}\text { Correlation } \\
\text { coefficient }\end{array}$} & \multirow{2}{*}{$\mathrm{dk}$} & \multirow[b]{2}{*}{$t_{\cos t}$} & \multicolumn{2}{|c|}{ terilt } & \multirow{2}{*}{ Conclusion } \\
\hline & & & $a=0,05$ & $\alpha=0,01$ & \\
\hline 0,483 & 247 & $8,667^{* *}$ & 1,970 & 2,596 & $\begin{array}{c}\text { Very } \\
\text { Signicant }\end{array}$ \\
\hline \multicolumn{6}{|c|}{ Significant requirements: $t$ coum $>t_{\text {tatle }}$} \\
\hline
\end{tabular}

Similarly, based on qualitative research, the results of interview analysis, observation and documentation in five Private Islamic High Schools in Jambi Province, it can be seen that there is a tendency for transformational leadership relationships with job satisfaction that strengthens the results of quantitative research.

From the findings obtained in this 2-stage research it can be seen that transformational leadership which is the behavior of a leader who directs his subordinates to use the values that exist today towards the vision and mission that has been set will be able to contribute to increase job satisfaction.

From the results of testing the hypothesis shows that there is a functional relationship between transformational leadership and job satisfaction with the regression equation $\hat{\mathrm{Y}}=76.287+0.467 \mathrm{X}$ with a value of $t=8.667>t$ table $(\alpha=0.05)=1.970$ and $F_{\text {table }}(\alpha$ 
$=0.01)=2,596$ which means that the significance of regression is significant. The functional relationship is linear as evidenced by the linearity test with the value of $\mathrm{t}$ count $=8.667<\mathrm{t}$ table $(\alpha=0.05)=1.970$ and $\mathrm{t}$ table $(\alpha$ $=0.01)=2.596$ which means significant or regression is linear. The value of the resulting correlation coefficient of 0.483 shows that any increase in the score of transformational leadership will increase job satisfaction.

The coefficient of determination between transformational leadership and job satisfaction is ry = 0.233 . This means that $23.3 \%$ of job satisfaction is the result of the operation of transformational leadership, while $76.7 \%$ is contributed by other variables that have a relationship with increased job satisfaction. The findings obtained in this study indicate that transformational leadership is the behavior of a leader who directs his subordinates to use the values that exist today towards the vision and mission that has been set.

This is in accordance with the theory put forward by Bernard M. Bass \& Ronald E. Riggio defines transformational leadership as a behavior that stimulates and inspires followers to achieve results and in the process of developing their leadership abilities, vision and goals given by their organization, challenges themselves to innovate, solve problems, and develop leadership skills for subordinates through direction, mentoring, and giving challenges and support. "Transformational leaders, on the other hand, are those who stimulate and inspire followers to both achieve extraordinary outcomes and, in the process, develop their own leadership capacity."

Transformational leadership is the behavior of a leader who directs his subordinates to use existing values towards the vision and mission that has been set. Thus a lecturer who has a high quality of transformational leadership will have job satisfaction.

The results of previous research studies have proven that transformational leadership has a positive relationship with job satisfaction, including research conducted by Yayuk Eka Setyo Wati, concluding that leadership has a significant effect on employee job satisfaction, this is indicated by a $p$ value of 0,000 so that $\mathrm{H} 1$ is received with a significance level $(\mathrm{p}<0.05)$.

In this analysis proves that the variable transformational leadership with job satisfaction has a coefficient of determination of ry $=0.233$. This means that transformational leadership contributes to job satisfaction by showing that the degree of relationship (correlation) between independent variables with the dependent variable is $23.3 \%$. This means that the higher the transformational leadership, the higher the job satisfaction, and vice versa, the lower the transformational leadership, the lower the job satisfaction. By finding facts and data in the analysis of this study, it increasingly supports previous research regarding the existence of a positive relationship between transformational leadership and job satisfaction.

Similarly, based on qualitative research, the results of the analysis of interviews, observation and documentation at three Private Islamic Universities in Jambi Province, can be known to have a tendency of the relationship between transformational leadership and job satisfaction. This shows that there is a strengthening of quantitative research as a result of testing the hypothesis which states that there is a functional relationship between transformational leadership and job satisfaction with significant regression and shows that any increase in transformational leadership scores will increase job satisfaction.

From the findings obtained in this 2-stage research it can be seen that transformational leadership is the behavior of a leader who directs his subordinates to use the values that exist today towards the vision and mission that has been determined, able to contribute to increase job satisfaction.

\section{CONCLUSION}

After conducting the quantitative research stage through the process of analyzing the results of data processing, statistical calculations, testing hypotheses and discussion of research results which are then strengthened by qualitative research stages through the process of observation, in-depth interviews and document collection, the research on the relationship of Organizational Culture, Transformational Leadership, Work Motivation with Job Satisfaction Private Islamic University lecturers in Jambi Province produce conclusions detailed as follows:

There is a very significant positive relationship between transformational leadership and job satisfaction with a correlation coefficient of ry = 0.483 ( $\mathrm{p}<0.01)$ and the coefficient of determination (ry2) ${ }^{2}=0.233$ and is supported by the regression equation $\hat{Y}=76.287+0.467 \mathrm{X}$. This means that the higher the transformational leadership, the higher the level of job satisfaction is predicted. Based on the results of data processing in this study there is a positive relationship between transformational leadership and job satisfaction, indicating that with increasing transformational leadership, job satisfaction will also increase. Some efforts that can be done to improve job satisfaction by increasing indicators of transformational leadership are by prioritizing improvements in indicators that have a low score, so that it can also increase the acquisition of high organizational values.

Indicators of transformational leadership that can be further developed in improving job satisfaction include the efforts of lecturers in improving the behavior of a leader who directs his subordinates to use the values that exist today towards the vision and 
mission that has been set. Efforts that can be made are by improving several aspects in accordance with the indicators of transformational leadership, namely increasing the ideal influence, inspiration that motivates, intellectual stimulation, and individual/ individual attention.

With these indicators increasing, transformational leadership will increase and job satisfaction is expected to increase as well.

\section{REFERENCES}

Bahar Agus Setiawan dan Abd. Muhith. Transformasional Leadership: Ilustrasi di Bidang Organisasi Pendidikan. Jakarta: Raja Grafindo Persada, 2013, p. 97

Bass, Bernard M. \& Ronald E. Riggio. Transformational Leadership. New Jersey: Lawrence Erlbaum Associates, Publishers, 2006.

Colquit, Jason A., Jefrey A. Lefine and Michel J. Wessor.Organizational Improving Performance and Commitment In The Workplace. New York: McGraw Hill, Irwin, 2009.

Gardner and Avolio (1998) dalam Paul E. Spector.Industrial and Organizational Psychology: Research and Practice, ,(USA : John Wiley \& Sons, Inc., 2006), pp. 349-350

Gary A. Yuki, Leadership in Organizations, (New York: Pearson Education International, 2006), pp..251-254.

Gibson, James L., Ivancevich, John M., Donnelly, James H., dan Konopaske, Robert. Organization Behavior, Structure, Processes. Twelfth Edition. Singapore: McGraw-Hill, 2006.

Greenberg, Jerald \& Robert A. Baron.Behavior in Organizations. New Jersey : Pearson International Inc., 2008.

Kenneth N. Wexley dan Gary A. Yuki. Perilaku Organisasi dan Psikologi Personalia, terjemahan Muh.. Shobaruddin, (Jakarta: Asli Mahasatya, 2005), p. 160.

Kinicki, Angelo and R. Kreitner, 2005, Organizational Behavior Key concepts skills and best Practice, Mc Graw-Hill, New York, hal. 125.

Laurie J. Mullins. Management and Organizational Behavior, (New York and London: Routledge. 2005 ). pp. 106.

Leslie W. Rue and Lioyd. L Byars. Supervision Key Link to Produktivity. (New York:Mc. Grow Hill, 2007)pp. 278-279.

Stephen L. MacShane \& Mary Ann von Glinow, Organizational Behavior, (New York : McGraw Hill Irwin, 2010), pp. 371-378.

Sugiyono.Statistik untuk Penelitian. Bandung: Alfabeta, 2005.

Sugiyono.Metode Penelitian Kuantitatif, Kualitatif dan $R \& D$. Bandung: Alfabeta, 2011.
T. Hani Handoko. Manajemen Personalia dan SDM, (Yogyakarta, BPFE.2008). h. 193.

Yuki, Gary A. Leadership in Organizations. New York: Pearson Education International, 2006. 